\title{
Antiaging of Cucurbitane Glycosides from Fruits of Momordica charantia L.
}

\author{
Xueli Cao, Yujuan Sun, Yanfei Lin, Yanjun Pan, Umer Farooq, Lan Xiang (D, \\ and Jianhua Qi \\ College of Pharmaceutical Sciences, Zhejiang University, Yu Hang Tang Road 866, Hangzhou 310058, China \\ Correspondence should be addressed to Lan Xiang; lxiang@zju.edu.cn and Jianhua Qi; qijianhua@zju.edu.cn
}

Received 10 September 2017; Revised 21 December 2017; Accepted 11 January 2018; Published 25 March 2018

Academic Editor: Carolina G. Llorente

Copyright (c) 2018 Xueli Cao et al. This is an open access article distributed under the Creative Commons Attribution License, which permits unrestricted use, distribution, and reproduction in any medium, provided the original work is properly cited.

\begin{abstract}
Methanol extracts of Momordica charantia L. fruits are extensively studied for their antiaging activities. A new cucurbitane-type triterpenoid (1) and nine other known compounds (2-10) were isolated, and their structures were determined according to their spectroscopic characteristics and chemical derivatization. Biological evaluation was performed on a K6001 yeast bioassay system. The results indicated that all the compounds extended the replicative lifespan of K6001 yeast significantly. Compound 9 was used to investigate the mechanism involved in the increasing of the lifespan. The results indicated that this compound significantly increases the survival rate of yeast under oxidative stress and decreases ROS level. Further study on gene expression analysis showed that compound 9 could reduce the levels of UTH1 and SKN7 and increase SOD1 and SOD2 gene expression. In addition, it could not extend the lifespan of the yeast mutants of Uth1, Skn7, Sod1, and Sod2. These results demonstrate that compound 9 exerts antiaging effects via antioxidative stress and regulation of UTH1, SKN7, SOD1, and SOD2 yeast gene expression.
\end{abstract}

\section{Introduction}

Fruits of Momordica charantia L. are edible healthy vegetable in Asia and commonly known as bitter melon or bitter gourd because of their bitter taste. Given their nutritional potential, they are used as traditional Chinese herbal medicine to treat several ailments, such as diabetes, constipation, abdominal pain, kidney stones, piles, pneumonia, and improve appetite [1-5]. M. charantia contains biologically active phytochemicals, such as polysaccharides, proteins, flavonoids, glycosides, saponins, steroids, alkaloids, essential oils, and triterpenes [5-10]. Many of these phytochemicals exhibit antitumor, anti-inflammatory, immunomodulation, and antidiabetic activities and the ability to reduce oxidative stress [5].

Aging is a dominating risk factor for age-related diseases, including cancer, metabolic disease, cardiovascular disease, and neurodegenerative illnesses [11]. As the aging population is increasing dramatically throughout the world, aging has drawn great attention because of huge expenses for medical care and serious consequences of the related diseases. Interventions that delay aging were found to have a greater effect on the quality of life compared with disease-specific approaches [12]. In our previous studies [13-17], a yeast mutant K6001 was employed in the bioassay system, and ganodermasides $\mathrm{A}-\mathrm{D}$, phloridzin, nolinospiroside $\mathrm{F}$, and parishin with significant antiaging potential from natural sources were obtained.

Basing on the K6001 bioassay system, we isolated one novel cucurbitane glycoside (1) and nine known cucurbitane-type triterpenoids (2-10) from the fruits of M. charantia L. (Figure 1). Essential studies on the action mechanism suggested that these cucurbitane glycosides could improve the antioxidative properties of yeasts. The yeast genes of youth 1 (UTH1), skinhead-7 (SKN7), and superoxide dismutase $(S O D)$ may also be involved in the action.

\section{Material and Methods}

2.1. General. The chemical reagents used were of HPLC grade and purchased from TEDIA (Rhode Island, USA). The others were of analytical grade and obtained from Sinopharm Chemical Reagent Co. Ltd. (Shanghai, China). 


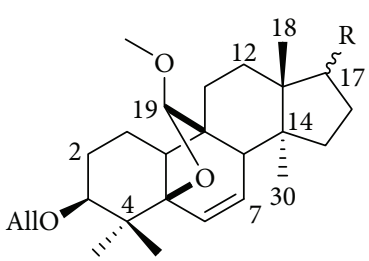

$\mathrm{R}={ }_{23}^{21}$<smiles>CC(C)C/C=C/C(C)(C)O</smiles><smiles>CO[C@@H](C=C(C)C)CC(C)C</smiles><smiles>CO[C@@H](C=C(C)C)CC(C)C</smiles>

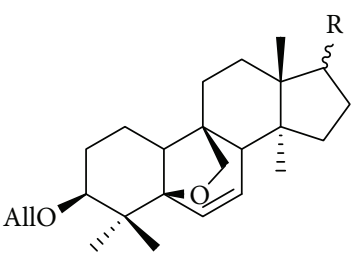<smiles>CO[C@H]1C=C2C(CC[C@@H](O)C2(C)C)[C@@]2(C)CC[C@]3(C)[C@@H]([C@H](C)C/C=C/C(C)(C)O)CC[C@]3(C)C12</smiles>

$1 \mathrm{R}=$<smiles>C[Te][Te][Te]</smiles><smiles>C=C(C)C=CCCCCC</smiles><smiles>CC(C)C/C=C/C(C)(C)O</smiles><smiles>CO[C@@H](C=C(C)C)CC(C)C</smiles><smiles>COC(C)(C)/C=C/CC(C)C</smiles>

Figure 1: Chemical structures of compounds 1-10.

The preparative HPLC system was equipped with two ELITE P-230 pumps and an UV detector. Optical rotations were determined on a JASCO P-1030 digital polarimeter. High-resolution ESI-TOF-MS analyses were performed on an Agilent Technologies 6224A Accurate-Mass TOF LC/ MS system (Santa Clara, CA, USA). Nuclear magnetic resonance (NMR) spectra were recorded on a Bruker AV III-500 spectrometer (Bruker, Billerica, MA, USA). Column chromatography was performed over the silica gel (200-300 mesh, Yantai Chemical Industry Research Institute, Yantai, China) or reversed phase $\mathrm{C} 18$ (Octadecylsilyl, ODS) silica gel (Cosmosil 75C 18 -OPN, Nacalai Tesque, Japan).

2.2. Plant Material and Yeast Strains. Fruits of M. charantia were purchased from Liangzhu market of Hangzhou, Zhejiang Province, China, 2011. The identity of this plant was confirmed by an associate professor Liurong Chen, and a voucher specimen (number 20110712) was preserved in Zhejiang University Institute of Materia Medica. The yeast strains BY4741 and mutants of uth1, skn7, sod1, and sod2 with K6001 background are from Prof. Matsuura in Chiba University, and K6001 strain with W303 background is from Prof. Breitenbach in Salzburg University.

2.3. Extraction and Isolation. About $1.5 \mathrm{~kg}$ (dry weight) of the material was smashed and extracted with methanol $(\mathrm{MeOH})$ for 3 days with shaking at room temperature. The extract was filtered and concentrated to obtain a crude extract $(224 \mathrm{~g})$, which was partitioned with ethyl acetate (EtOAc) and water. The active EtOAc layer ( $30 \mathrm{~g}$ ) was subjected to a silica gel open column with $n$-hexane/acetone (99:1, 98:2, 95:5, $90: 10,80: 20,70: 30,60: 40,50: 50,20: 80$, and $0: 100)$ and acetone/MeOH $(50: 50$ and $0: 100)$. The EtOAc layer yielded nine fractions after the combination based on TLC analysis. The eighth active fraction of $4.0 \mathrm{~g}$ ( $13.9 \mathrm{~g}$ in total) was subsequently separated by ODS open column with $\mathrm{MeOH} / \mathrm{H}_{2} \mathrm{O}$ $(60: 40,70: 30,75: 25,80: 20,90: 10$, and $100: 0)$, and 11 samples were obtained (fr.1-fr.11). The four active samples of fr.6-fr.9 were further separated as follows:

Fr.6 (600 mg) was introduced to an ODS open column with $\mathrm{MeOH} / \mathrm{H}_{2} \mathrm{O}(70: 30,73: 27,75: 25,77: 23,80: 20$, $83: 17,85: 15$, and $100: 0$ ) to yield nine samples (fr.6-1fr.6-9). Fr.6-6 (72 mg) was further separated by a silica gel open column chromatography with dichloromethane $\left(\mathrm{CH}_{2} \mathrm{Cl}_{2}\right) / \mathrm{MeOH}(100: 0,99: 1,98: 2,97.5: 2.5,95: 5,90: 10$, and $0: 100$ ), and the sixth active fraction $(11.6 \mathrm{mg}$ ) was purified by HPLC [C30-UG-5 $(\varphi 10 \times 250 \mathrm{~mm}$, Nomura Chemical), mobile phase: acetonitrile $(\mathrm{MeCN}) / \mathrm{H}_{2} \mathrm{O}(90: 10)$, flow rate: $3 \mathrm{~mL} / \mathrm{min}$, and detector: $210 \mathrm{~nm}$ ] and yielded compound $1\left(4.6 \mathrm{mg}, t_{\mathrm{R}}=33.5 \mathrm{~min}\right)$ and compound 2 $\left(1.0 \mathrm{mg}, t_{\mathrm{R}}=30.7 \mathrm{~min}\right)$.

Fr.7 (277 mg) was separated in a silica gel open column with chloroform $\left(\mathrm{CHCl}_{3}\right) / \mathrm{MeOH} \quad(100: 0,98: 2,95: 5$, $90: 10$, and $0: 100)$ and yielded fr.7-1-fr.7-11. Subsequently, fr.7-7 (63 mg) was subjected to ODS open column chromatography with $\mathrm{MeOH} / \mathrm{H}_{2} \mathrm{O}(70: 30,75: 25,80: 20,90: 10$, and $100: 0)$, and the second fraction $(37.8 \mathrm{mg})$ was purified by HPLC [C30-UG-5 $(\varphi 10 \times 250 \mathrm{~mm}$, Nomura Chemical), mobile phase: $\mathrm{MeCN} / \mathrm{H}_{2} \mathrm{O}(62: 38)$, flow rate: $3 \mathrm{~mL} / \mathrm{min}$, and detector: $210 \mathrm{~nm}$ ] and yielded compound $3(10.6 \mathrm{mg}$, $\left.t_{\mathrm{R}}=15.9 \mathrm{~min}\right)$, compound $4\left(1.8 \mathrm{mg}, t_{\mathrm{R}}=17.1 \mathrm{~min}\right)$, and compound 5 ( $\left.1.9 \mathrm{mg}, t_{\mathrm{R}}=18.7 \mathrm{~min}\right)$.

Fr.8 (340 mg) was introduced to a silica open column with $n$-hexane/ $\mathrm{CHCl}_{3}(50: 50,30: 70$, and $0: 100)$ and $\mathrm{CHCl}_{3} / \mathrm{MeOH}(97: 3,95: 5,90: 10$, and $0: 100)$ to give fr.8-1-fr.8-9. Then, fr.8-4 (49 mg) was purified by HPLC 
[CAPCELL PAKC ${ }_{18}$, Shiseido $(\varphi 10 \times 250 \mathrm{~mm})$, mobile phase: $\mathrm{MeCN} / \mathrm{H}_{2} \mathrm{O}$ (63:37), flow rate: $3 \mathrm{~mL} / \mathrm{min}$, and detector: $210 \mathrm{~nm}]$ and yielded compound $6\left(10.2 \mathrm{mg}, t_{\mathrm{R}}=20.2 \mathrm{~min}\right)$, compound $7\left(4.9 \mathrm{mg}, t_{\mathrm{R}}=22.9 \mathrm{~min}\right)$, and compound 8 $\left(1.3 \mathrm{mg}, t_{\mathrm{R}}=32.0 \mathrm{~min}\right)$.

Fr.9 (600 mg) was separated by silica gel open column with $\mathrm{CHCl}_{3} / \mathrm{MeOH}(100: 0,100: 1,100: 2,100: 3,100: 5$, $90: 10$, and $0: 100$ ), and fr.9-1-fr.9-8 were obtained. Then, fr.9-4 $(332 \mathrm{mg})$ was further separated by ODS open column with $\mathrm{MeOH} / \mathrm{H}_{2} \mathrm{O}(90: 10,95: 5$, and $100: 0)$, and the third fraction $(42 \mathrm{mg}$ ) was purified by HPLC [CAPCELL PAKC $_{18}$, Shiseido $(\varphi 10 \times 250 \mathrm{~mm})$, mobile phase: $\mathrm{MeCN} /$ $\mathrm{H}_{2} \mathrm{O}$ (60:40), flow rate: $3 \mathrm{~mL} / \mathrm{min}$, and detector: $210 \mathrm{~nm}$ ] and yielded compound $9\left(5.0 \mathrm{mg}, t_{\mathrm{R}}=28.7 \mathrm{~min}\right)$ and compound $10\left(8.0 \mathrm{mg}, t_{\mathrm{R}}=33.8 \mathrm{~min}\right)$.

2.3.1. Compound 1. White solid; $[\alpha]_{\mathrm{D}}^{20}-78.6\left(c 0.2, \mathrm{CH}_{3} \mathrm{OH}\right)$; high-resolution ESI-TOF-MS $\mathrm{m} / \mathrm{z}$ 653.4029, calculated for $\mathrm{C}_{37} \mathrm{H}_{58} \mathrm{O}_{8} \mathrm{Na}(\mathrm{M}+\mathrm{Na})^{+} 653.4024$; data of ${ }^{1} \mathrm{H}$ NMR and ${ }^{13} \mathrm{C}$ NMR are shown in Table 1.

2.3.2. Charantoside IV (2). Colorless solid; $[\alpha]_{\mathrm{D}}^{28}-143.9$ (c 0.16, $\left.\mathrm{CH}_{3} \mathrm{OH}\right)$; MS m/z $623(\mathrm{M}+\mathrm{Na})^{+}, \mathrm{C}_{36} \mathrm{H}_{56} \mathrm{O}_{7} \mathrm{Na}$; ${ }^{13} \mathrm{C}$ NMR $\left(125 \mathrm{MHz}\right.$, pyridine- $\left.d_{5}\right): \delta=15.4,19.3,19.3$, $19.3,20.6,21.5,24.2,26.0,28.0,28.7,31.4,33.8,37.2$, $39.4,40.5,40.5,45.7,45.9,49.3,51.0,52.7,63.7,69.7$, $72.9,73.5,76.6,80.5,85.5,86.3,104.3,115.1,130.3$, 130.4, 134.6, 135.1, and 142.9. The structure was identified based on comparison of MS, ${ }^{1} \mathrm{H}$, and ${ }^{13} \mathrm{C}$ NMR data with literature [18].

2.3.3. Momordicoside $F_{2}$ (3). White solid; $[\alpha]_{\mathrm{D}}^{20}-101.0$ (c $\left.0.94, \mathrm{CHCl}_{1}: \mathrm{CH}_{3} \mathrm{OH}=1: 1\right) ; \mathrm{MS} m / z 641(\mathrm{M}+\mathrm{Na})^{+}$, $\mathrm{C}_{36} \mathrm{H}_{58} \mathrm{O}_{8} \mathrm{Na} ;{ }^{13} \mathrm{C}$ NMR $\left(125 \mathrm{MHz}\right.$, pyridine- $\left.d_{5}\right): \delta=15.4$, $19.3,19.3,20.6,21.5,24.3,26.0,28.0,28.6,31.3,31.3$, $31.4,33.8,37.0,39.4,39.9,40.5,45.7,45.8,49.3,50.6$, $52.7,63.7,69.7,70.1,72.9,73.5,76.6,80.5,85.5,86.3$, $104.2,124.6,130.4,134.6$, and 142.1. The structure was identified based on comparison of MS, ${ }^{1} \mathrm{H}$, and ${ }^{13} \mathrm{C}$ NMR data with literature [19].

2.3.4. Goyaglycoside-b (4). White solid; $[\alpha]_{\mathrm{D}}^{20}-100.7$ (c 0.2 , $\left.\mathrm{CH}_{3} \mathrm{OH}\right) ; \mathrm{MS} \mathrm{m} / z 671(\mathrm{M}+\mathrm{Na})^{+}, \mathrm{C}_{37} \mathrm{H}_{60} \mathrm{O}_{9} \mathrm{Na} ;{ }^{13} \mathrm{C} \mathrm{NMR}$ $\left(125 \mathrm{MHz}\right.$, pyridine- $\left.d_{5}\right): \delta=15.3,19.1,19.3,20.4,21.7,23.7$, $25.3,27.8,28.6,31.3,31.3,31.3,34.3,37.0,39.5,40.0,42.0$, $42.6,45.7,48.6,48.7,50.8,58.1,63.7,69.7,70.1,72.2,74.2$, $77.0,83.9,86.0,102.8,112.8,124.7,132.0,133.6$, and 142.1. The structure was identified based on comparison of MS, ${ }^{1} \mathrm{H}$, and ${ }^{13} \mathrm{C}$ NMR data with literature [4].

2.3.5. Karaviloside III (5). White solid; $[\alpha]_{\mathrm{D}}^{28}+70.9$ (c 0.1 , $\left.\mathrm{CH}_{3} \mathrm{OH}\right) ; \mathrm{MS} m / z 657(\mathrm{M}+\mathrm{Na})^{+}, \mathrm{C}_{37} \mathrm{H}_{62} \mathrm{O}_{8} \mathrm{Na} ;{ }^{13} \mathrm{C} \mathrm{NMR}$ $\left(125 \mathrm{MHz}\right.$, pyridine- $\left.d_{5}\right): \delta=16.0,18.5,19.4,23.1,26.3,28.3$, $29.3,29.4,29.6,30.8,31.3,31.3,33.2,34.8,35.4,37.1,39.8$, $40.0,42.4,46.7,48.7,49.3,50.6,56.6,63.8,69.7,70.1,72.5$, $73.9,76.1,78.0,88.3,105.4,119.5,124.2,142.2$, and 148.4. The structure was identified based on comparison of MS, ${ }^{1} \mathrm{H}$, and ${ }^{13} \mathrm{C}$ NMR data with literature [20].
TABle 1: ${ }^{1} \mathrm{H}-\mathrm{NMR}(500 \mathrm{MHz})$ and ${ }^{13} \mathrm{C}-\mathrm{NMR}(125 \mathrm{MHz})$ data of compound 1 in pyridine- $d_{5}$.

\begin{tabular}{|c|c|c|}
\hline \multirow{2}{*}{ Position } & \multicolumn{2}{|c|}{ Compound 1} \\
\hline & $\delta_{\mathrm{H}}(J$ in $\mathrm{Hz})$ & $\delta_{\mathrm{C}}$ \\
\hline $1 \alpha$ & 1.46 & 19.2 \\
\hline $1 \beta$ & 1.91 & - \\
\hline $2 \alpha$ & 1.75 & 27.8 \\
\hline $2 \beta$ & 2.17 & - \\
\hline $3 \alpha$ & 3.73 (br s) & 83.9 \\
\hline 4 & - & 39.5 \\
\hline 5 & - & 86.0 \\
\hline 6 & $6.18(\mathrm{dd}, 2.0,9.7)$ & 133.6 \\
\hline 7 & $5.63(\mathrm{dd}, 3.6,9.7)$ & 132.0 \\
\hline $8 \beta$ & 3.15 (br s) & 42.7 \\
\hline 9 & - & 48.6 \\
\hline $10 \alpha$ & $2.48(\mathrm{dd}, 5.6,12.7)$ & 42.1 \\
\hline $11 \alpha$ & 1.75 & 23.7 \\
\hline $11 \beta$ & 1.68 & - \\
\hline $12 \alpha$ & 1.60 & 31.3 \\
\hline $12 \beta$ & 1.55 & - \\
\hline 13 & - & 45.8 \\
\hline 14 & - & 48.7 \\
\hline $15 \alpha$ & 1.31 & 34.3 \\
\hline $15 \beta$ & 1.31 & - \\
\hline $16 \alpha$ & 1.94 & 28.7 \\
\hline $16 \beta$ & 1.32 & - \\
\hline $17 \alpha$ & 1.50 & 51.2 \\
\hline 18 & $0.91(\mathrm{~s})$ & 15.3 \\
\hline 19 & $4.91(\mathrm{~s})$ & 112.8 \\
\hline 20 & 1.50 & 37.3 \\
\hline 21 & $0.95(\mathrm{~d}, 5.6)$ & 19.4 \\
\hline $22 \alpha$ & 1.83 & 40.5 \\
\hline $22 \beta$ & 2.32 & - \\
\hline 23 & $5.76(\mathrm{~m})$ & 130.4 \\
\hline 24 & $6.32(\mathrm{~d}, 15.3)$ & 135.1 \\
\hline 25 & - & 143.0 \\
\hline $26 \alpha$ & $4.96(\mathrm{~s})$ & 115.1 \\
\hline $26 \beta$ & $5.10(\mathrm{~s})$ & - \\
\hline 27 & $1.92(\mathrm{~s})$ & 19.3 \\
\hline 28 & $0.83(\mathrm{~s})$ & 25.3 \\
\hline 29 & $1.47(\mathrm{~s})$ & 21.7 \\
\hline 30 & $0.90(\mathrm{~s})$ & 20.4 \\
\hline$-\mathrm{OCH}_{3}$ & $3.52(\mathrm{~s})$ & 58.1 \\
\hline $1^{\prime}$ & $5.52(\mathrm{~d}, 7.8)$ & 102.8 \\
\hline $2^{\prime}$ & $3.94(\mathrm{dt}, 2.6,7.6)$ & 74.2 \\
\hline $3^{\prime}$ & $4.76(\mathrm{~d}, 2.8)$ & 72.2 \\
\hline $4^{\prime}$ & $4.23(\mathrm{td}, 2.8,9.3)$ & 69.7 \\
\hline $5^{\prime}$ & $4.50(\mathrm{~m})$ & 77.0 \\
\hline $6^{\prime} \alpha$ & $4.43(\mathrm{~m})$ & 63.7 \\
\hline $6^{\prime} \beta$ & $4.57(\mathrm{~m})$ & - \\
\hline
\end{tabular}


2.3.6. Charantoside VI (6). White solid; $[\alpha]_{\mathrm{D}}^{28}-67.2$ ( $\left.\mathrm{CH}_{3} \mathrm{OH}\right) ; \mathrm{MS} \mathrm{m} / z 655(\mathrm{M}+\mathrm{Na})^{+}, \mathrm{C}_{37} \mathrm{H}_{60} \mathrm{O}_{8} \mathrm{Na} ;{ }^{13} \mathrm{C}$ NMR $\left(125 \mathrm{MHz}\right.$, pyridine- $\left.d_{5}\right): \delta=15.2,18.8,19.3,20.3,20.6,21.5$, $24.2,26.0,26.3,28.0,29.1,31.5,33.8,34.2,39.4,40.5,43.4$, $45.7,45.9,49.3,51.7,52.7,55.7,63.7,69.7,72.9,73.5,76.6$, $76.8,80.5,85.6,86.3,104.2,127.8,130.4,134.5$, and 135.5. The structure was identified based on comparison of MS, ${ }^{1} \mathrm{H}$, and ${ }^{13} \mathrm{C}$ NMR data with literature [18].

2.3.7. Charantagenin E (7). Colorless solid; $[\alpha]_{\mathrm{D}}^{28}-104.3$ (c $\left.0.11, \mathrm{CH}_{3} \mathrm{OH}\right)$; MS m/z $685(\mathrm{M}+\mathrm{Na})^{+}, \mathrm{C}_{38} \mathrm{H}_{62} \mathrm{O}_{9} \mathrm{Na}$; ${ }^{13} \mathrm{C}$ NMR $\left(125 \mathrm{MHz}\right.$, pyridine- $\left.d_{5}\right): \delta=15.1,18.8,19.1$, $20.4,20.4,21.7,23.7,25.3,26.2,27.8,29.0,31.4,34.2$, $34.2,39.5,42.0,42.6,43.4,45.7,48.5,48.7,51.8,55.7$, $58.0,63.7,69.7,72.2,74.2,76.9,77.0,83.9,86.0,102.8$, $112.8,127.8,132.0,133.5$, and 135.5. The structure was identified according to the comparison among MS, ${ }^{1} \mathrm{H}$, and ${ }^{13} \mathrm{C}$ NMR data in literature [21].

2.3.8. Charantoside II (8). White solid; $[\alpha]_{\mathrm{D}}^{20}-67.1$ (c 0.2 , $\left.\mathrm{CH}_{3} \mathrm{OH}\right) ; \mathrm{MS} \mathrm{m} / z 685(\mathrm{M}+\mathrm{Na})^{+}, \mathrm{C}_{38} \mathrm{H}_{62} \mathrm{O}_{9} \mathrm{Na} ;{ }^{13} \mathrm{C} \mathrm{NMR}$ $\left(125 \mathrm{MHz}\right.$, pyridine- $\left.d_{5}\right): \delta=15.2,18.5,19.1,19.3,20.4,21.6$, 23.7, 25.2, 26.2, 27.7, 28.8, 31.4, 33.2, 34.2, 39.5, 42.0, 42.6, 43.7, 45.8, 48.5, 48.7, 51.7, 56.0, 58.0, 63.6, 69.6, 72.2, 74.1, $75.2,76.9,84.0,85.9,102.9,112.8,128.3,132.0,133.5$, and 134.9. The structure was identified based on comparison of MS, ${ }^{1} \mathrm{H}$, and ${ }^{13} \mathrm{C}$ NMR data with literature [18].

2.3.9. Momordicoside $G$ (9). White solid; $[\alpha]_{\mathrm{D}}^{28}-90.2$ ( c 1.0, $\left.\mathrm{CH}_{3} \mathrm{OH}\right) ; \mathrm{MS} \mathrm{m} / z 655(\mathrm{M}+\mathrm{Na})^{+}, \mathrm{C}_{37} \mathrm{H}_{60} \mathrm{O}_{8} \mathrm{Na} ;{ }^{13} \mathrm{C}$ NMR $\left(125 \mathrm{MHz}\right.$, pyridine- $\left.d_{5}\right): \delta=15.5,19.3,20.6,21.5,24.3,26.0$, $26.5,26.9,28.0,28.6,31.5,33.8,36.7,39.4,40.1,40.5,45.7$, $45.9,49.3,50.6,50.7,52.7,63.7,65.3,69.7,72.9,73.5,75.3$, $76.6,80.6,85.5,86.3,104.2,128.8,130.4,134.6$, and 138.1. The structure was identified based on comparison of MS, ${ }^{1} \mathrm{H}$, and ${ }^{13} \mathrm{C}$ NMR data with literature [19].

2.3.10. Goyaglycoside-d (10). White solid; $[\alpha]_{\mathrm{D}}^{28}-124.9$ (c 0.1 , $\left.\mathrm{CH}_{3} \mathrm{OH}\right) ; \mathrm{MS} m / z 685(\mathrm{M}+\mathrm{Na})^{+}, \mathrm{C}_{38} \mathrm{H}_{62} \mathrm{O}_{9} \mathrm{Na} ;{ }^{13} \mathrm{C} \mathrm{NMR}$ $\left(125 \mathrm{MHz}\right.$, pyridine- $\left.d_{5}\right): \delta=15.3,19.1,19.3,20.4,21.6,23.7$, $25.3,26.4,26.9,27.8,28.6,31.3,34.3,36.8,39.5,40.1,42.0$, $42.6,45.7,48.5,48.7,50.5,50.8,58.1,63.7,69.6,72.2,74.1$, $75.3,77.0,83.9,86.0,102.8,112.8,128.9,132.0,133.6$, and 138.0. The structure was identified based on comparison of MS, ${ }^{1} \mathrm{H}$, and ${ }^{13} \mathrm{C}$ NMR data with literature [4].

2.4. Acid Hydrolysis and Sugar Analysis of Compound 1. The absolute configuration of sugar moiety of compound 1 was determined according to a previously reported method $[22,23]$. Briefly, compound $1(0.5 \mathrm{mg})$ in anhydrous $2.0 \mathrm{M}$ $\mathrm{HCl}$ in $\mathrm{MeOH}(1 \mathrm{~mL})$ was heated at $80^{\circ} \mathrm{C}$ with reflux for $4 \mathrm{~h}$. The reaction solution was evaporated and partitioned between chloroform and water. The residue of aqueous layer was heated with $0.5 \mathrm{mg}$ L-cysteine methyl ester in pyridine $(200 \mu \mathrm{L})$ at $60^{\circ} \mathrm{C}$ for $1 \mathrm{~h}$; then, $o$-tolyl isothiocyanate dissolved in $100 \mu \mathrm{L}$ pyridine $(7 \mathrm{mg} / \mathrm{mL})$ was added to the reaction mixture and further reacted at $60^{\circ} \mathrm{C}$ for $1 \mathrm{~h}$. After that, the reaction mixture was dried and analyzed by LC/HRESIMS with the following conditions: Agilent Extend C18 column $(3.5 \mu \mathrm{m}, 3.0 \times 100 \mathrm{~mm})$; DAD detection, $210 \mathrm{~nm} ; t=0 \mathrm{~min}$
$\mathrm{CH}_{3} \mathrm{OH} / \mathrm{H}_{2} \mathrm{O} /$ formic acid $(30: 70: 0.1), t=15 \mathrm{~min} \mathrm{CH}_{3} \mathrm{OH} /$ $\mathrm{H}_{2} \mathrm{O} /$ formic acid $(60: 40: 0.1)$; and flow rate: $0.45 \mathrm{~mL} / \mathrm{min}$.

The allose thiocarbamate standards were prepared in the same procedure. Given that L-allose is limitedly available, the retention time of L-allose thiocarbamate derivative was obtained by reacting $\mathrm{D}$-allose with $\mathrm{D}$-cysteine methyl ester. The basis of this approach is the fact that the $t_{\mathrm{R}}$ values of $\mathrm{D}$ - and L-enantiomers are reversed when $\mathrm{D}$-cysteine methyl ester is used [22].

2.5. Lifespan Assay. The bioassay method was performed as described in a previous study [13]. Briefly, K6001 or mutants with K6001 background were grown on a YPGalactose medium consisting of $3 \%$ galactose, $2 \%$ hipolypeptone, and $1 \%$ yeast extract or on a YPGlucose medium containing 2\% glucose instead of galactose. Agar plates were prepared by adding $2 \%$ agar to the medium. For screening, the K6001 yeast strain was first incubated in the galactose medium for $24 \mathrm{~h}$ with shaking and then centrifuged. The yeast pellet was washed with PBS three times. The cells were then diluted and counted using a hemocytometer, and approximately 4000 cells were plated on glucose agar plates containing different concentrations of samples. The plates were stored in an incubator at $28^{\circ} \mathrm{C}$. After $48 \mathrm{~h}$, the yeast cells in the plates were observed with a microscope. For each plate, 40 colonies were selected randomly, and the number of their daughter cells was counted and analyzed.

2.6. Antioxidative Stress Method. Antioxidative stress assay was performed as previously described with minor modification [16]. BY4741 yeast was inoculated in $5 \mathrm{~mL}$ of YPGlucose medium and cultured at $28^{\circ} \mathrm{C}$ with shaking for $24 \mathrm{~h}$. The yeast cells at $0.1 \mathrm{OD}_{600}$ were transferred in $20 \mathrm{~mL}$ of new YPGlucose medium and incubated with compound 9 at 1 and $3 \mu \mathrm{M}$ or resveratrol (Res, positive control) at $10 \mu \mathrm{M}$ for $12 \mathrm{~h}$.

For the first method, $5 \mu \mathrm{L}$ aliquot after double dilution from each group was dropped in the same YPGlucose agar plate mixed with $9 \mathrm{mM} \mathrm{H}_{2} \mathrm{O}_{2}$, and the plate was incubated at $28^{\circ} \mathrm{C}$ for 4 days. The growth rates of the yeast cells in different groups were compared and photographed.

Another antioxidative stress assay was used to validate the accuracy of the experiment. Approximately 200 cells mixed with the test samples were spreaded on YPGlucose agar plates with or without $5 \mathrm{mM} \mathrm{H}_{2} \mathrm{O}_{2}$ and cultured at $28^{\circ} \mathrm{C}$ for $48 \mathrm{~h}$. The survival rates of the sample groups were counted and compared with those of the control group.

2.7. Determination of ROS Level in Yeast. The ROS assay procedure was the same with a previous study [17]. BY4741 yeast cells were cultured as described in the experiment above and incubated with compound 9 at 1 or $3 \mu \mathrm{M}$ for $23 \mathrm{~h}$. Changes in intracellular ROS levels of the yeast were determined using an ROS assay kit (Beyotime, Jiangsu, China) and a fluorescent plate reader (Spectra Max M2, Molecular Devices, San Francisco, CA, USA). A total of $1 \mathrm{~mL}$ of cultured broth was obtained, treated with $10 \mu \mathrm{M}$ DCFH-DA at $28^{\circ} \mathrm{C}$ in dark, and then shaken by vortexing at $160 \mathrm{rpm}$ at $15 \mathrm{~min}$ intervals for $1 \mathrm{~h}$. The yeast cells were subsequently washed 


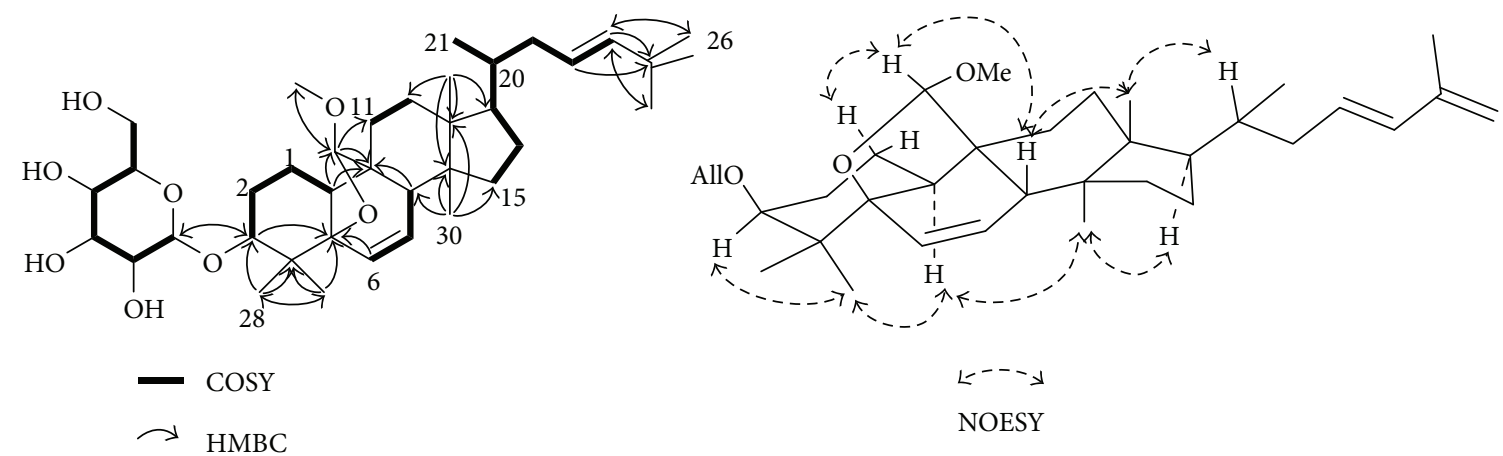

Figure 2: Gross structure of compound 1 with ${ }^{1} \mathrm{H}-{ }^{1} \mathrm{H}$ COSY, selected HMBC, and NOESY correlations.

with PBS, and their DCF fluorescence was measured by a fluorescent plate reader at excitation and emission wavelengths of 488 and $525 \mathrm{~nm}$, respectively.

2.8. Real-Time Quantitative PCR Analysis. BY4741 yeast cells were cultured in glucose medium following the addition of $0,1,3 \mu \mathrm{M}$ compound 9. RNA was extracted from yeast cells in the exponential phase through the hotphenol method. Reverse transcription was performed using a cloned AMV first-strand cDNA synthesis kit (Invitrogen, California, USA) with oligo (dT) adaptor primers and $5 \mu \mathrm{g}$ of yeast total RNA. Real-time PCR was performed using the CFX96-Touch (Bio-Rad, Hercules, USA) and SYBR Premix EX Taq ${ }^{\text {TM }}$ (TaKaRa, Otsu, Japan). Thermal cycling parameters for UTH1 and SKN7: 40 cycles, $94^{\circ} \mathrm{C}$ for $15 \mathrm{~s}$, $55.4^{\circ} \mathrm{C}$ for $15 \mathrm{~s}$, and $68^{\circ} \mathrm{C}$ for $20 \mathrm{~s}$; for SOD1 and SOD2: 40 cycles, $94^{\circ} \mathrm{C}$ for $15 \mathrm{~s}, 60^{\circ} \mathrm{C}$ for $25 \mathrm{~s}$, and $72^{\circ} \mathrm{C}$ for $10 \mathrm{~s}$. Primers used were as follows: for UTH1, sense $5^{\prime}$-CGC CTC TTC CTC TT- $3^{\prime}$ and antisense $5^{\prime}$-ACC ATC GGA AGG TTG TTC AG- $3^{\prime}$; for $S K N 7$, sense $5^{\prime}$-AGT TGT CAG CGA CGG TCT TT- $3^{\prime}$ and antisense 5'-GCT GTG GCA CCA TCT AGG TT- $3^{\prime}$; for SOD1 sense $5^{\prime}$-CAC CAT TTT CGT CCG TCT TT- $3^{\prime}$ and antisense $5^{\prime}$-TGG TTG TGT CTC TGC TGG TC-3 ${ }^{\prime}$; for SOD2, sense $5^{\prime}$-CTC CGG TCA AAT CAA CGA AT- $3^{\prime}$ and antisense $5^{\prime}$-CCT TGG CCA GAA GAT CTG AG-3'; for TUB1, sense $5^{\prime}$-CCA AGG GCT ATT TAC GTG GA- $3^{\prime}$ and antisense $5^{\prime}$-GGT GTA ATG GCC TCT TGC AT- $3^{\prime}$. The amount of UTH1, SKN7, SOD1, and SOD2 was normalized to that of TUB1.

2.9. Statistical Analysis. One-way analysis of variance was performed using GraphPad Prism biostatistics software (San Diego, CA, USA) to analyze the data. Significant differences were compared by two-tailed multiple $t$-tests with Student-Newman-Keuls test. Data were expressed as means \pm SEM of triplicate experiments. A $P<0.05$ was considered statistically significant.

\section{Results and Discussion}

3.1. Structure Elucidation of Compound 1. Compound 1 has the molecular formula $\mathrm{C}_{37} \mathrm{H}_{58} \mathrm{O}_{8}$ as determined by HR-ESIMS measurement. The ${ }^{1} \mathrm{H}$ NMR data showed six methyl groups at $\delta_{\mathrm{H}} 0.83(3 \mathrm{H}, \mathrm{s}), 0.90(3 \mathrm{H}, \mathrm{s}), 0.91(3 \mathrm{H}, \mathrm{s})$, $0.95(3 \mathrm{H}, \mathrm{d}, J=5.6 \mathrm{~Hz}), 1.47(3 \mathrm{H}, \mathrm{s})$, and $1.92(3 \mathrm{H}, \mathrm{s})$, along with six olefinic protons at $\delta_{\mathrm{H}} 4.96(1 \mathrm{H}, \mathrm{s}), 5.10(1 \mathrm{H}, \mathrm{s}), 5.63$ $(1 \mathrm{H}, \mathrm{dd}, J=3.6,9.7 \mathrm{~Hz}), 5.76(1 \mathrm{H}, \mathrm{m}), 6.18(1 \mathrm{H}, \mathrm{dd}, J=2.10$, $9.7 \mathrm{~Hz})$, and $6.32(1 \mathrm{H}, \mathrm{d}, J=15.3 \mathrm{~Hz})$. Several multiple peaks at $\delta_{\mathrm{H}} 3.94-4.76$ and the signal of an anomeric proton $\left[\delta_{\mathrm{H}}\right.$ $5.52(1 \mathrm{H}, \mathrm{d}, J=7.8 \mathrm{~Hz})]$ indicated the existence of a sugar moiety. The ${ }^{13} \mathrm{C}$ NMR data revealed the presence of 37 carbon signals. With the combined signals of ${ }^{13} \mathrm{C}$ NMR and DEPT, the 37 carbon signals were attributed to six olefinic carbons $\left(\delta_{\mathrm{C}} 115.1,130.4,132.0,133.6,135.1\right.$, and 143.0), one anomeric carbon $\left(\delta_{\mathrm{C}} 102.8\right)$, one oxygenated quaternary carbon $\left(\delta_{\mathrm{C}} 86.0\right)$, six oxymethines $\left(\delta_{\mathrm{C}} 69.7,72.2,74.2,77.0\right.$, 83.9 , and 112.8$)$, one oxymethylene $\left(\delta_{C} 63.7\right)$, one methoxy group $\left(\delta_{\mathrm{C}} 58.1\right)$, four quaternary $\mathrm{sp}^{3}$ carbons $\left(\delta_{\mathrm{C}} 39.5,45.8\right.$, 48.6, and 48.7), four methines $\left(\delta_{\mathrm{C}} 37.3,42.1,42.7\right.$, and 51.2), seven methylenes $\left(\delta_{\mathrm{C}} 19.2,23.7,27.8,28.7,31.3,34.3\right.$, and 40.5$)$, and six methyl groups $\left(\delta_{\mathrm{C}} 15.3,19.3,19.4,20.4\right.$, 21.7, and 25.3). Detailed analysis of the ${ }^{1} \mathrm{H}^{1}{ }^{1} \mathrm{H}$ COSY spectra led to the determination of the partial structures depicted by the bonds (Figure 2, in bold bonds). In the HMBC spectrum, these partial structures were connected to yield the following gross structures: $\mathrm{H}-3$ to $\mathrm{C}-5 ; \mathrm{H}-6$ to $\mathrm{C}-5 ; \mathrm{H}-8$ to $\mathrm{C}-9 ; \mathrm{H}-10$ to C-9; $\mathrm{CH}_{3}-18$ to C-12, C-13, C-14, and C-17; H-19 to C-9, $\mathrm{C}-10, \mathrm{C}-11$, and $-\mathrm{OCH}_{3} ; \mathrm{CH}_{3}-28$ to $\mathrm{C}-3, \mathrm{C}-4$, and $\mathrm{C}-29$; $\mathrm{CH}_{3}-29$ to C-4, C-5, and C-28; $\mathrm{CH}_{3}-30$ to C-8, C-13, C-14, and $\mathrm{C}-15 ; \mathrm{H}-23$ to $\mathrm{C}-25 ; \mathrm{H}-24$ to $\mathrm{C}-25, \mathrm{C}-26$, and $\mathrm{C}-27$; $\mathrm{H}-26$ to $\mathrm{C}-24 ; \mathrm{CH}_{3}-27$ to $\mathrm{C}-24$; and $-\mathrm{OCH}_{3}$ to $\mathrm{C}-19$. The signals of $\mathrm{H}-3$ to $\mathrm{C}-1^{\prime}$ of allose and anomeric proton $\mathrm{H}-1^{\prime}$ of allose to C-3 in the HMBC indicated the location of the sugar moiety (Figure 2). The $\beta$ anomeric configuration of allose was determined from its coupling constant $J$ $(7.8 \mathrm{~Hz})$ of anomeric protons $\left(\delta_{\mathrm{H}} 5.52\right)$. The absolute configuration of the sugar moiety was further confirmed by the degradation of compound 1 and through the comparison of the retention time of its aldose thiocarbamate derivative $\left(t_{\mathrm{R}}=9.287 \mathrm{~min}\right)$ with those of the following aldose thiocarbamate standards: L-cysteine-D-allose $\left(t_{\mathrm{R}}=9.127 \mathrm{~min}\right)$ and $\mathrm{D}$-cysteine-D-allose $\left(t_{\mathrm{R}}=7.460 \mathrm{~min}\right)$.

The relative stereochemistry of compound 1 was deduced by nuclear overhauser enhancement spectroscopy (NOESY) analysis. As shown in Figure 2, the broad singlet signal of H-3 appeared at $\delta_{\mathrm{H}} 3.73$ thereby suggested the $\alpha$ configuration of this proton. The NOESY correlations of 


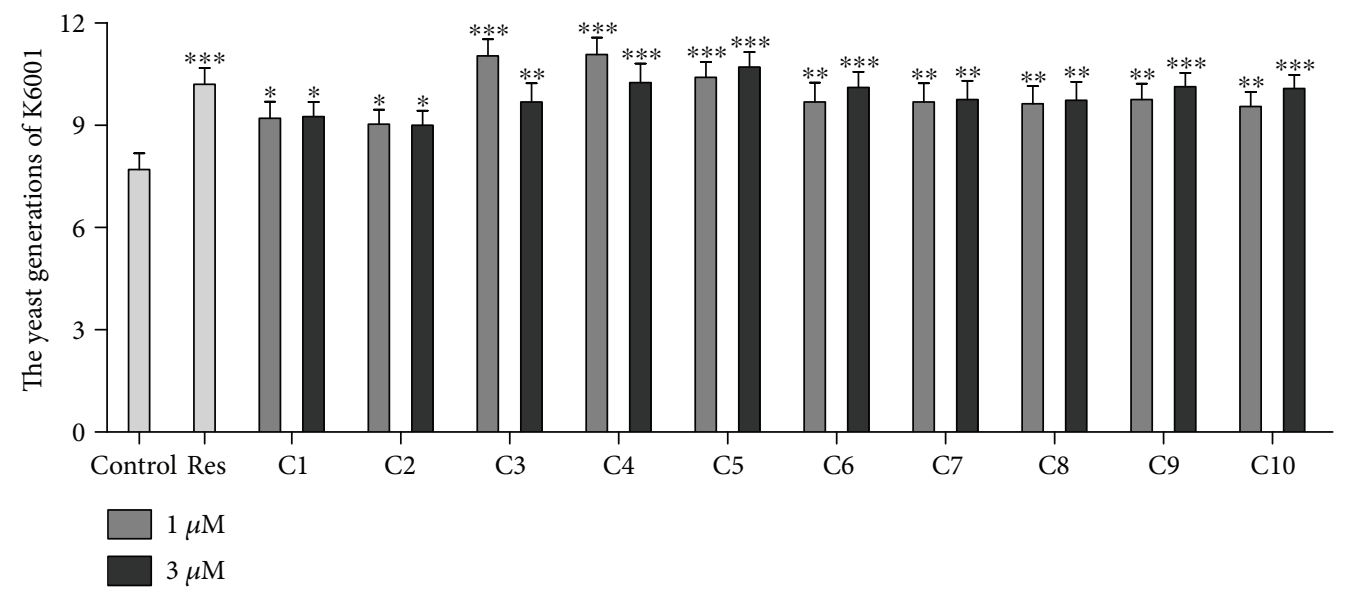

FIGURE 3: Effect of compounds 1-10 on the replicative lifespan of K6001 yeast strain. The average lifespan of K6001 was as follows: control $(7.70 \pm 0.48)$; Res at $10 \mu \mathrm{M}\left(10.20 \pm 0.42^{* * *}\right)$; compound 1 at $1 \mu \mathrm{M}\left(9.20 \pm 0.49^{*}\right)$ and at $3 \mu \mathrm{M}\left(9.25 \pm 0.42^{*}\right)$; compound 2 at $1 \mu \mathrm{M}\left(9.03 \pm 0.43^{*}\right)$ and at $3 \mu \mathrm{M}\left(9.00 \pm 0.42^{*}\right)$; compound 3 at $1 \mu \mathrm{M}\left(11.03 \pm 0.53^{* * *}\right)$ and at $3 \mu \mathrm{M}\left(9.68 \pm 0.55^{* *}\right)$; compound 4 at $1 \mu \mathrm{M}\left(11.08 \pm 0.50^{* * *}\right)$ and at $3 \mu \mathrm{M}\left(10.25 \pm 0.56^{* * *}\right)$; compound 5 at $1 \mu \mathrm{M}\left(10.40 \pm 0.45^{* * *}\right)$ and at $3 \mu \mathrm{M}\left(10.70 \pm 0.45^{* * *}\right)$; compound 6 at $1 \mu \mathrm{M}\left(9.68 \pm 0.57^{* *}\right)$ and at $3 \mu \mathrm{M}\left(10.10 \pm 0.46^{* * *}\right)$; compound 7 at $1 \mu \mathrm{M}\left(9.68 \pm 0.55^{* *}\right)$ and at $3 \mu \mathrm{M}\left(9.75 \pm 0.55^{* *}\right)$; compound 8 at $1 \mu \mathrm{M}\left(9.63 \pm 0.52^{* *}\right)$ and at $3 \mu \mathrm{M}\left(9.73 \pm 0.55^{* *}\right)$; compound 9 at $1 \mu \mathrm{M}\left(9.75 \pm 0.47^{* *}\right)$ and at $3 \mu \mathrm{M}\left(10.13 \pm 0.41^{* * *}\right)$; and compound 10 at $1 \mu \mathrm{M}\left(9.55 \pm 0.42^{* *}\right)$ and at $3 \mu \mathrm{M}\left(10.08 \pm 0.39^{* * *}\right)\left({ }^{*} P<0.05,{ }^{* *} P<0.01\right.$, and ${ }^{* * *} P<0.001$, compared with the control).

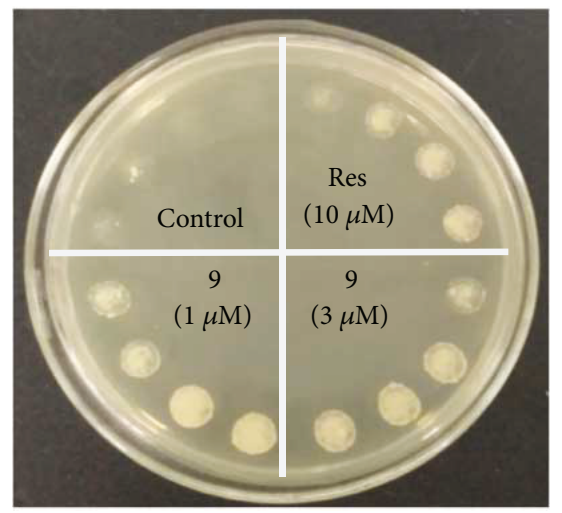

(a)

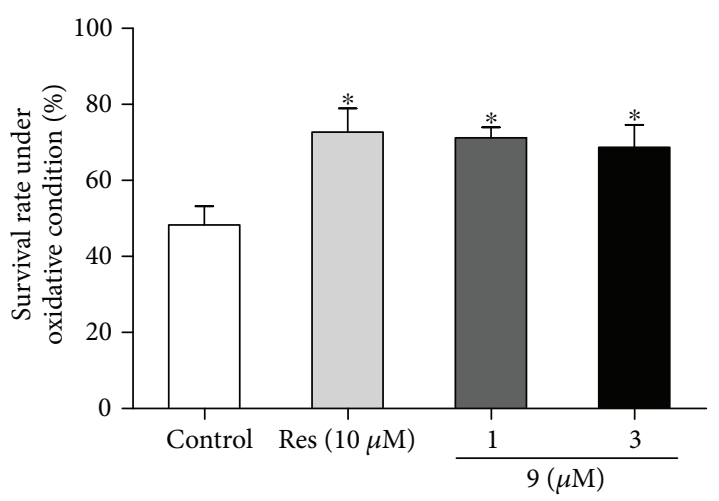

(b)

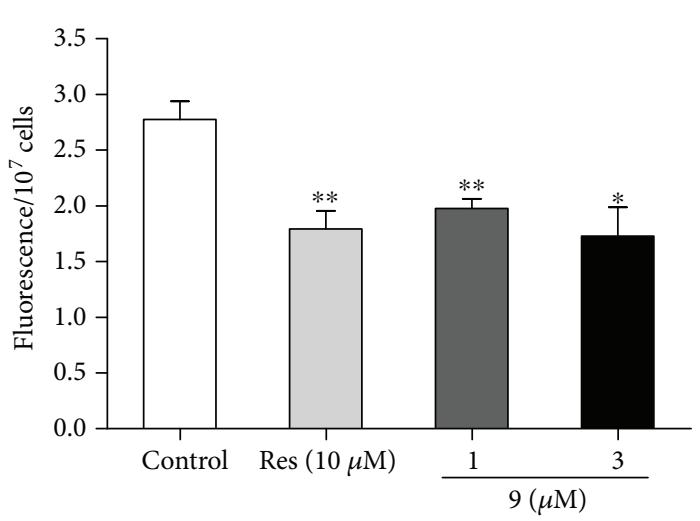

(c)

FIGURE 4: Effect of compound 9 on the antioxidative ability of yeast cells and ROS level of yeast. (a) BY4741 yeast cells in the control group and compound 9-treated groups were dropped in the same YPGlucose agar plate mixed with $9 \mathrm{mM} \mathrm{H}_{2} \mathrm{O}_{2}$. After four days, the growth of yeast cells in different groups was photographed. (b) Effect of compound 9 on the survival rates of yeast under oxidative stress condition. Control, $48.31 \pm 4.94$; Res, $72.74 \pm 6.19^{*}$; compound 9 at $1 \mu \mathrm{M}, 71.21 \pm 2.75^{*}$ and at $3 \mu \mathrm{M}, 68.73 \pm 5.89^{*}$. The experiment was conducted at least thrice. Vertical bars represent the mean \pm SEM of three assays $\left({ }^{*} P<0.05\right)$. (c) The change of ROS level of yeast after administration compound 9 at 1 , $3 \mu \mathrm{M}$. Control, $2.77 \pm 0.15^{* *}$; Res, $1.79 \pm 0.15^{* *}$; compound 9 at $1 \mu \mathrm{M}, 1.98 \pm 0.08^{* *}$, and at $3 \mu \mathrm{M}, 1.73 \pm 0.22^{*}$. Vertical bars represent the mean \pm SEM of 6 repeats $\left({ }^{*} P<0.05\right.$ and ${ }^{* *} P<0.01$, compared with the control). 


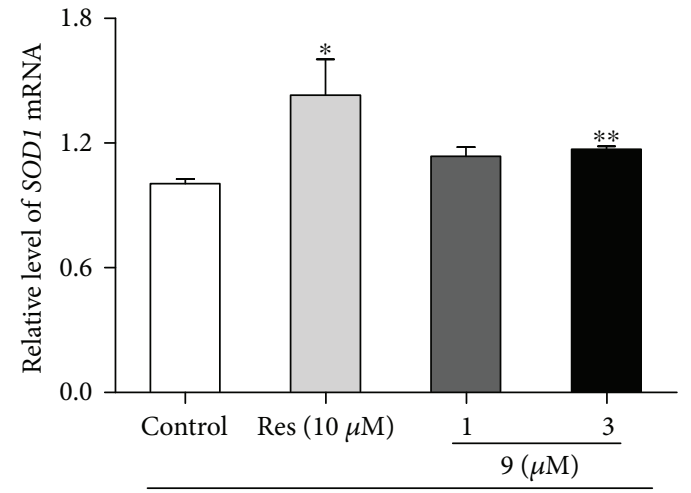

$12 \mathrm{~h}$

(a)

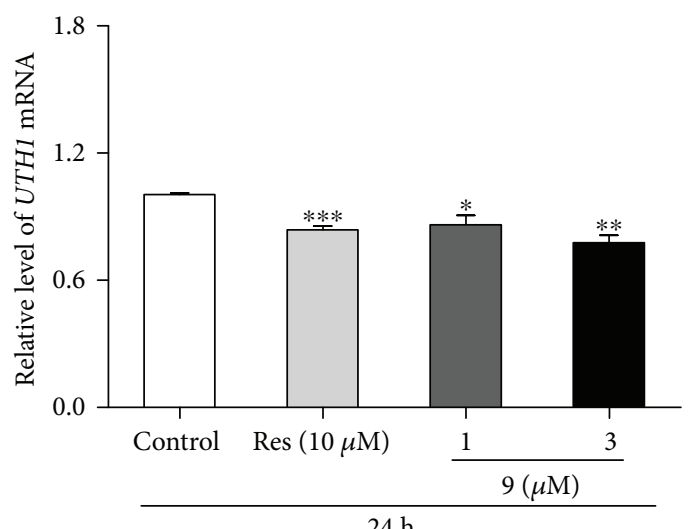

(c)

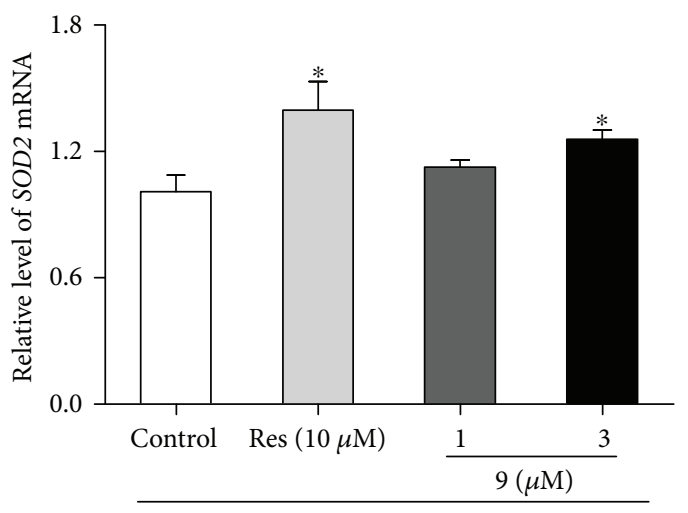

(b)

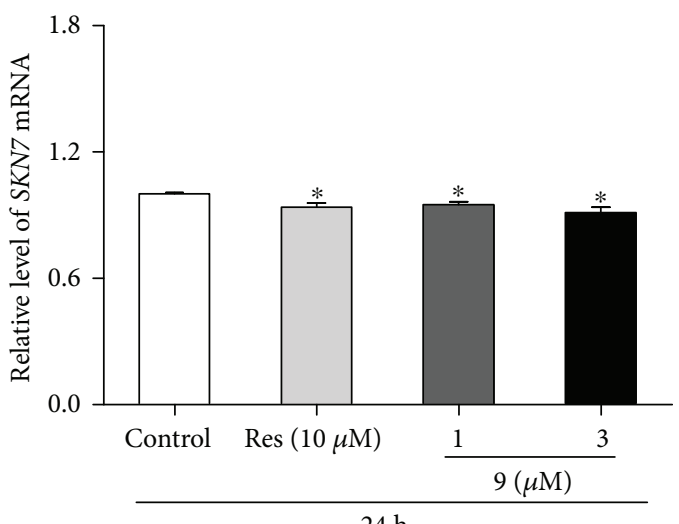

(d)

Figure 5: Effects of compound 9 on SOD1 (a), SOD2 (b), UTH1 (c), and SKN7 (d) yeast gene expression. The gene levels of BY4741 yeast cells were tested after treated with compound 9 at 1 and $3 \mu \mathrm{M}$. Compound 9 significantly increased SOD 1 and SOD 2 yeast gene level at $12 \mathrm{~h}$ and inhibited UTH1 and SKN7 yeast gene expression at $24 \mathrm{~h}$. Amounts of the mRNA above were normalized to that of TUB1. The results were displayed as mean \pm SEM for three independent experiments $\left({ }^{*} P<0.05,{ }^{* *} P<0.01\right.$, and ${ }^{* * *} P<0.001$, compared with the control group).

major cross-peaks of $\mathrm{H}-3 \alpha / \mathrm{Me}-28, \mathrm{Me}-28 / \mathrm{H}-10, \mathrm{H}-10 / \mathrm{Me}-$ 30 , and $\mathrm{Me}-30 / \mathrm{H}-17$ indicated the $\alpha$-orientation of these protons. The correlations between $\mathrm{H}-1 \beta / \mathrm{H}-19, \mathrm{H}-19 / \mathrm{H}-8$, $\mathrm{H}-8 / \mathrm{Me}-18$, and $\mathrm{Me}-18 / \mathrm{H}-20$ suggested the $\beta$-orientation of these groups. The double bond at C-23 and C-24 was elucidated by COSY correlations, whereas the transgeometry was determined from the coupling constant, $J_{23-24}=15.3 \mathrm{~Hz}$.

The above evidence suggested that compound 1 was structurally similar to $(19 R, 23 E)-5 \beta, 19$-epoxy-19-methoxycucurbita-6, 23-25-trien-3 $\beta$-ol 3-O- $\beta$-D-allopyranoside (Figure 1).

3.2. Identification of the Known Compounds. Compounds 2-10 (Figure 1) were identified by comparing their spectroscopic data with those in literature.

3.3. Antiaging Activity in K6001 Yeast Strain. All isolated cucurbitane triterpenoids (1-10) were tested for antiaging activity through the K6001 bioassay method at different optimum concentrations. All the compounds at 1 and $3 \mu \mathrm{M}$ extended the replicative lifespan of K6001 significantly (Figure 3), demonstrating that the cucurbitane triterpenoids isolated from M. charantia L. fruits have antiaging effect in yeast.

3.4. Compound 9 Improves the Oxidative Resistance and Decreases ROS Production of Yeast. Studies on mechanism of action were conducted with compound 9 because of its abundance and good activity. Oxidative stress is one of the primary causes of aging, as indicated in various model organisms [24]. Therefore, the effect of compound 9 on the oxidative resistance of yeast was first tested. The growth of yeast cells was inhibited at $9 \mathrm{mM} \mathrm{H}_{2} \mathrm{O}_{2}$, whereas incubation with compound 9 at 1 or $3 \mu \mathrm{M}$ remitted the inhibition (Figure 4(a)). The effect was further confirmed in another assay. As shown in Figure 4(b), the survival rate of the control group was $48.31 \% \pm 4.94 \%$, whereas that in the experimental groups increased to $71.21 \% \pm 2.75 \%$ (compound 9 at $1 \mu \mathrm{M}, P<0.5$ ) and $68.73 \% \pm 5.89 \%$ (compound 9 at $3 \mu \mathrm{M}, P<0.5)$. The experiments indicated that compound 9 enhances the oxidative resistance of yeast cells. Furthermore, we detected the ROS level of yeast after administration compound 9 at 1 and $3 \mu \mathrm{M}$. As we expected, the ROS level of yeast in the resveratrol and compound 9 groups were significantly decreased compared with the control 


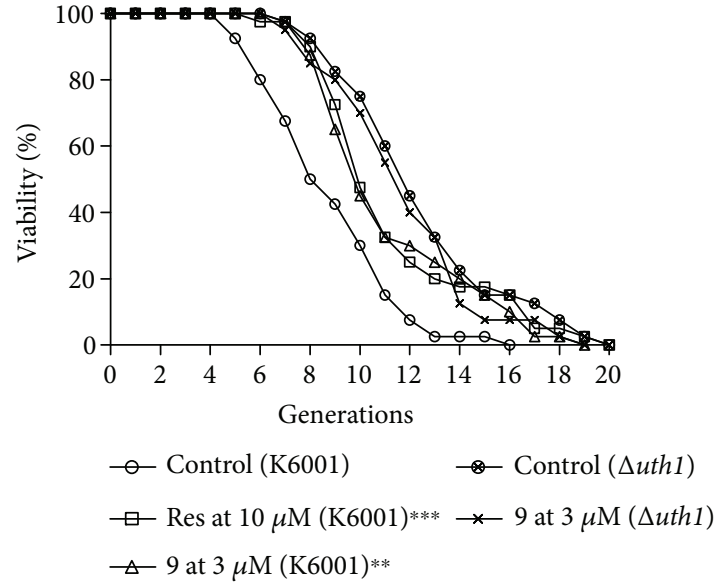

(a)

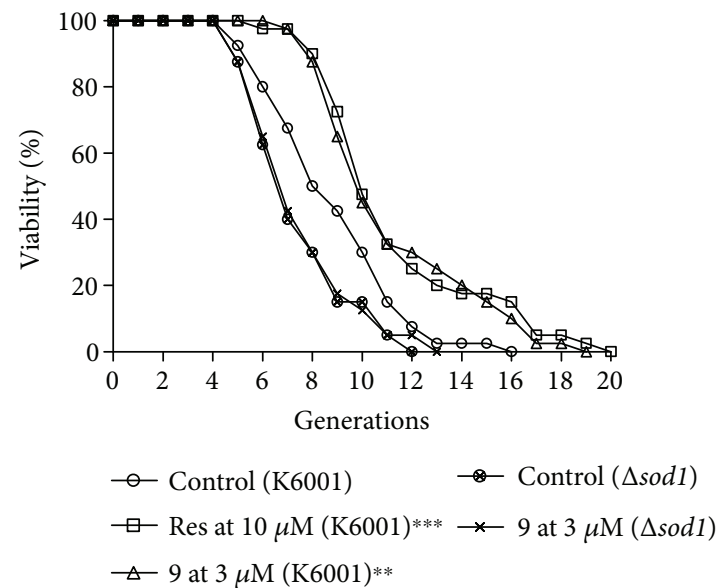

(c)

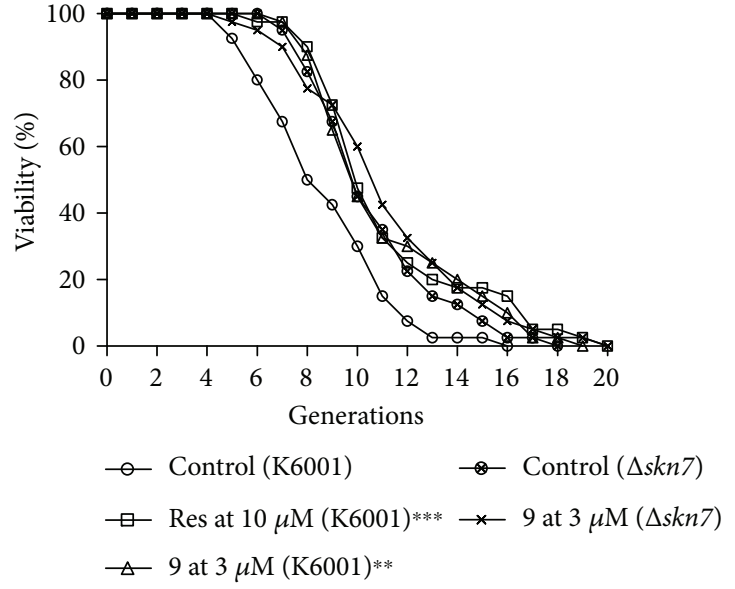

(b)

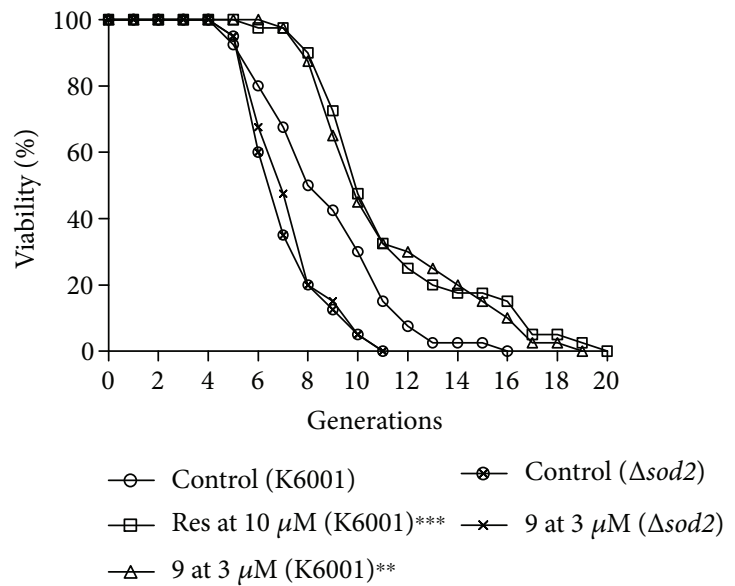

(d)

Figure 6: Effect of compound 9 on the replicative lifespan of $u t h 1$ (a), skn7 (b), sod1 (c), and sod2 (d) mutants. The average lifespan of K6001 in the control group was $7.93 \pm 0.41$; Res at $10 \mu \mathrm{M}, 10.45 \pm 0.52^{* * *}$; and compound 9 at $3 \mu \mathrm{M}, 10.33 \pm 0.49^{* *}$. (a) The average lifespan of $\Delta u t h 1$ in the control group was $11.60 \pm 0.51$ and compound 9 at $3 \mu \mathrm{M}, 10.95 \pm 0.46$. (b) The average lifespan of $\Delta s k n 7$ in the control group was $9.88 \pm 0.41$ and compound 9 at $3 \mu \mathrm{M}, 10.40 \pm 0.53$. (c) The average lifespan of $\Delta$ sod1 in the control group was $6.55 \pm 0.32$ and compound 9 at $3 \mu \mathrm{M}, 6.65 \pm 0.34$. (d) The average lifespan of $\Delta s o d 2$ in the control group was $6.28 \pm 0.25$ and compound 9 at $3 \mu \mathrm{M}$, $6.50 \pm 0.25\left({ }^{* *} P<0.01\right.$ and $\left.{ }^{* * *} P<0.001\right)$.

group (Figure 4(c), $P<0.01, P<0.01$, and $P<0.05$ ), respectively. These results suggested that compound 9 extended the replicative lifespan via inhibition of oxidative stress.

3.5. Compound 9 Extends Yeast Lifespan via Modification of UTH1, SKN7, SOD1, and SOD2 Gene Expression. It is well known that antioxidative stress is one of mechanisms of action for antiaging. UTH1 gene essentially takes part in oxidative stress regulation, and deletion of UTH1 gene will lead to extend the replicative lifespan of yeast [25]. SKN7 is upstream gene and is a stress response transcription factor in Saccharomyces cerevisiae [26]. Superoxide dismutases (SOD) are major ROS scavenging enzymes and can convert superoxide anion to hydrogen peroxide [24]. Real-time PCR analysis was performed to examine the molecular mechanism of compound 9-mediated lifespan extension. The significant gene expression reduction or increase of UTH1, SKN7, SOD1, and SOD2 was observed in the compound 9 treatment groups (Figure 5). These results suggested that compound 9 produced antiaging effect via regulation UTH1, SKN7, SOD1, and SOD2 yeast gene expression.

3.6. Antiaging Effects of Compound 9 Diminished in Uth1, Skn7, Sod1, and Sod2 Mutations with K6001 Background. To investigate the role of these genes in the antiaging activity of compound 9, we used the mutants of $u t h 1, \operatorname{skn} 7, \operatorname{sod} 1$, and sod2. As shown in Figure 6, compound 9 at $3 \mu \mathrm{M}$ did not affect the replicative lifespan of uth1 (Figure 6(a)) or skn7 mutants (Figure 6(b)), neither of sod1 (Figure 6(c)) or sod2 mutants (Figure 6(d)). These results were further indicated that these four genes were involved in the mechanism of action of compound 9 .

\section{Conclusions}

A novel cucurbitane-type triterpenoid and nine known compounds were isolated and identified from the fruits of M. charantia. All the compounds showed antiaging effect in 
yeast. The antiaging activities of these cucurbitane-type triterpenoids depended on their antioxidative ability and the regulation of the UTH1, SKN7, SOD1, and SOD2 yeast genes. Apart from being one of the most well-known vegetables and frequently used as a traditional medicine because of its health benefits, $M$. charantia has potential as an antiaging functional food.

\section{Conflicts of Interest}

The authors declare no financial or commercial conflict of interest.

\section{Authors' Contributions}

Xueli Cao and Yujuan Sun contributed equally to the article.

\section{Acknowledgments}

This work was supported by the NSFC (Grant nos. 21661140001, 81273385, and 21572204), International Science and Technology Cooperation Program of China (Grant no. 2014DFG32690), and Project of the Science and Technology Department of Zhejiang Province (Grant no. 2015C33132). The authors are grateful to Akira Matsuura (Chiba University, Japan) for the gifts of BY4741 and all mutations with the K6001 background and grateful to Michael Breitenbach (Salzburg University, Austria) for the gifts of K6001.

\section{References}

[1] G. Nagarani, A. Abirami, and P. Siddhuraju, "Food prospects and nutraceutical attributes of Momordica species: a potential tropical bioresources - a review," Food Science and Human Wellness, vol. 3, no. 3-4, pp. 117-126, 2014.

[2] X. Xu, B. Shan, C. H. Liao, J. H. Xie, P. W. Wen, and J. Y. Shi, "Anti-diabetic properties of Momordica charantia L. polysaccharide in alloxan-induced diabetic mice," International Journal of Biological Macromolecules, vol. 81, pp. 538-543, 2015.

[3] A. Raman and C. Lau, "Anti-diabetic properties and phytochemistry of Momordica charantia L. (Cucurbitaceae)," Phytomedicine, vol. 2, no. 4, pp. 349-362, 1996.

[4] T. Murakami, A. Emoto, H. Matsuda, and M. Yoshikawa, "Medicinal foodstuffs. XXI. Structures of new cucurbitanetype triterpene glycosides, goyaglycosides-a, -b, -c, -d, -e, -f, -g, and - $h$, and new oleanane-type triterpene saponins, goyasaponins I, II, and III, from the fresh fruit of Japanese Momordica charantia L.," Chemical and Pharmaceutical Bulletin, vol. 49, no. 1, pp. 54-63, 2001.

[5] J. K. Grover and S. P. Yadav, "Pharmacological actions and potential uses of Momordica charantia: a review," Journal of Ethnopharmacology, vol. 93, no. 1, pp. 123-132, 2004.

[6] R. Horax, N. Hettiarachchy, and P. Chen, "Characteristics and functionality enhancement by glycosylation of bitter melon (Momordica charantia) seed protein," Journal of Food Science, vol. 79, no. 11, pp. C2215-C2221, 2014.

[7] Z.-J. Li, J.-C. Chen, Y.-Y. Deng et al., "Two new cucurbitane triterpenoids from immature fruits of Momordica charantia," Helvetica Chimica Acta, vol. 98, no. 10, pp. 1456-1461, 2015.
[8] B. Zhang, C. Xie, Y. Wei, J. Li, and X. Yang, "Purification and characterisation of an antifungal protein, MCha-Pr, from the intercellular fluid of bitter gourd (Momordica charantia) leaves," Protein Expression and Purification, vol. 107, pp. 4349, 2015.

[9] O. Kenny, T. J. Smyth, C. M. Hewage, and N. P. Brunton, "Antioxidant properties and quantitative UPLC-MS analysis of phenolic compounds from extracts of fenugreek (Trigonella foenum-graecum) seeds and bitter melon (Momordica charantia) fruit," Food Chemistry, vol. 141, no. 4, pp. 42954302, 2013.

[10] F. Zhang, L. Lin, and J. Xie, "A mini-review of chemical and biological properties of polysaccharides from Momordica charantia," International Journal of Biological Macromolecules, vol. 92, pp. 246-253, 2016.

[11] M. Armanios, R. de Cabo, J. Mannick, L. Partridge, J. van Deursen, and S. Villeda, "Translational strategies in aging and age-related disease," Nature Medicine, vol. 21, no. 12, pp. 1395-1399, 2015.

[12] M. Kaeberlein, P. S. Rabinovitch, and G. M. Martin, "Healthy aging: the ultimate preventative medicine," Science, vol. 350, no. 6265, pp. 1191-1193, 2015.

[13] Y. Weng, L. Xiang, A. Matsuura, Y. Zhang, Q. Huang, and J. Qi, "Ganodermasides A and B, two novel anti-aging ergosterols from spores of a medicinal mushroom Ganoderma lucidum on yeast via UTH1 gene," Bioorganic \& Medicinal Chemistry, vol. 18, no. 3, pp. 999-1002, 2010.

[14] Y. Weng, J. Lu, L. Xiang et al., "Ganodermasides C and D, two new anti-aging ergosterols from spores of the medicinal mushroom Ganoderma lucidum," Bioscience, Biotechnology, and Biochemistry, vol. 75, no. 4, pp. 800-803, 2011.

[15] L. Xiang, K. Sun, J. Lu et al., "Anti-aging effects of phloridzin, an apple polyphenol, on yeast via the SOD and Sir2 genes," Bioscience, Biotechnology, and Biochemistry, vol. 75, no. 5, pp. 854-858, 2011.

[16] K. Sun, S. Cao, L. Pei, A. Matsuura, L. Xiang, and J. Qi, "A steroidal saponin from Ophiopogon japonicus extends the lifespan of yeast via the pathway involved in SOD and UTH1," International Journal of Molecular Sciences, vol. 14, no. 3, pp. 4461-4475, 2013.

[17] Y. Lin, Y. Sun, Y. Weng, A. Matsuura, L. Xiang, and J. Qi, "Parishin from Gastrodia elata extends the lifespan of yeast via regulation of Sir2/Uth1/TOR signaling pathway," Oxidative Medicine and Cellular Longevity, vol. 2016, Article ID 4074690, 11 pages, 2016.

[18] T. Akihisa, N. Higo, H. Tokuda et al., "Cucurbitane-type triterpenoids from the fruits of Momordica charantia and their cancer chemopreventive effects," Journal of Natural Products, vol. 70, no. 8, pp. 1233-1239, 2007.

[19] H. Okabe, Y. Miyahara, and T. Yamauchi, "Studies on the Constituents of Momordica charantia L. III. Characterization of New Cucurbitacin Glycosides of the Immature Fruits. Structures of Momordicosides G, $\mathrm{F}_{1}, \mathrm{~F}_{2}$ and I," Chemical and Pharmaceutical Bulletin, vol. 30, no. 11, pp. 3977-3986, 1982.

[20] S. Nakamura, T. Murakami, J. Nakamura, H. Kobayashi, H. Matsuda, and M. Yoshikawa, "Structures of new cucurbitane-type triterpenes and glycosides, karavilagenins and karavilosides, from the dried fruit of Momordica charantia L. in Sri Lanka," Chemical \& Pharmaceutical Bulletin, vol. 54, no. 11, pp. 1545-1550, 2006.

[21] X. Wang, W. Sun, J. Cao, H. Qu, X. Bi, and Y. Zhao, "Structures of new triterpenoids and cytotoxicity activities of 
the isolated major compounds from the fruit of Momordica charantia L.," Journal of Agricultural and Food Chemistry, vol. 60, no. 15, pp. 3927-3933, 2012.

[22] T. Tanaka, T. Nakashima, T. Ueda, K. Tomii, and I. Kouno, "Facile discrimination of aldose enantiomers by reversedphase HPLC," Chemical \& Pharmaceutical Bulletin, vol. 55, no. 6, pp. 899-901, 2007.

[23] F. Berrué, M. W. B. McCulloch, and P. Boland, "Isolation of steroidal glycosides from the Caribbean sponge Pandaros acanthifolium," Journal of Natural Products, vol. 75, no. 12, pp. 2094-2100, 2012.

[24] Y. Kong, S. E. Trabucco, and H. Zhang, "Oxidative stress, mitochondrial dysfunction and the mitochondria theory of aging," Interdisciplinary Topics in Gerontology, vol. 39, pp. 86-107, 2014.

[25] N. Camougrand, I. Kissova, G. Velours, and S. Manon, "Uth1p: a yeast mitochondrial protein at the crossroads of stress, degradation and cell death," FEMS Yeast Research, vol. 5, no. 2, pp. 133-140, 2004.

[26] V. Basso, S. Znaidi, V. Lagage et al., "The two-component response regulator $\mathrm{Skn} 7$ belongs to a network of transcription factors regulating morphogenesis in Candida albicans and independently limits morphogenesis-induced ROS accumulation," Molecular Microbiology, vol. 106, no. 1, pp. 157$182,2017$. 


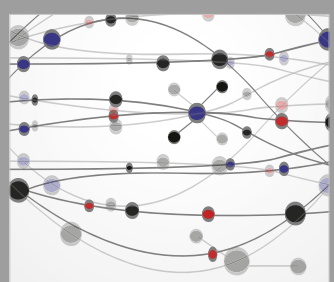

The Scientific World Journal
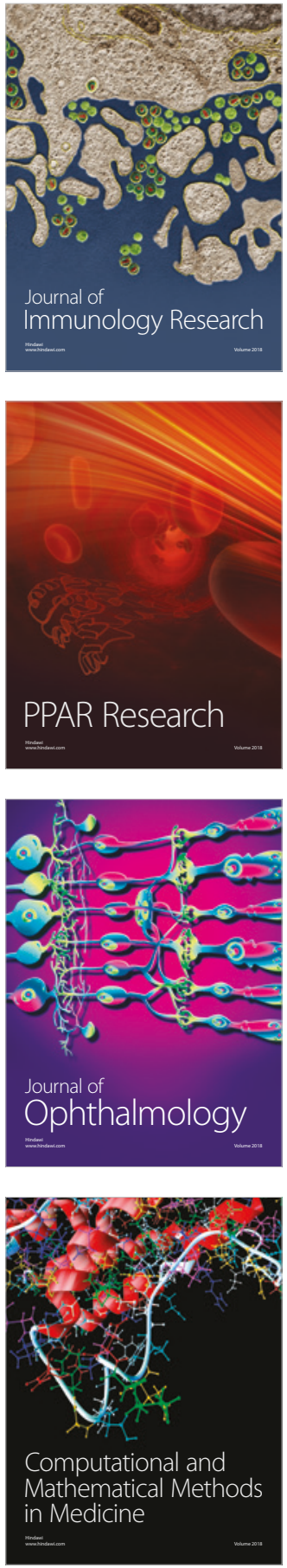

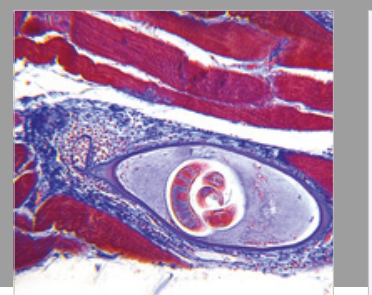

Gastroenterology Research and Practice

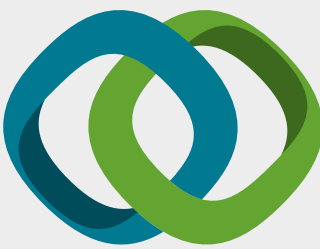

\section{Hindawi}

Submit your manuscripts at

www.hindawi.com
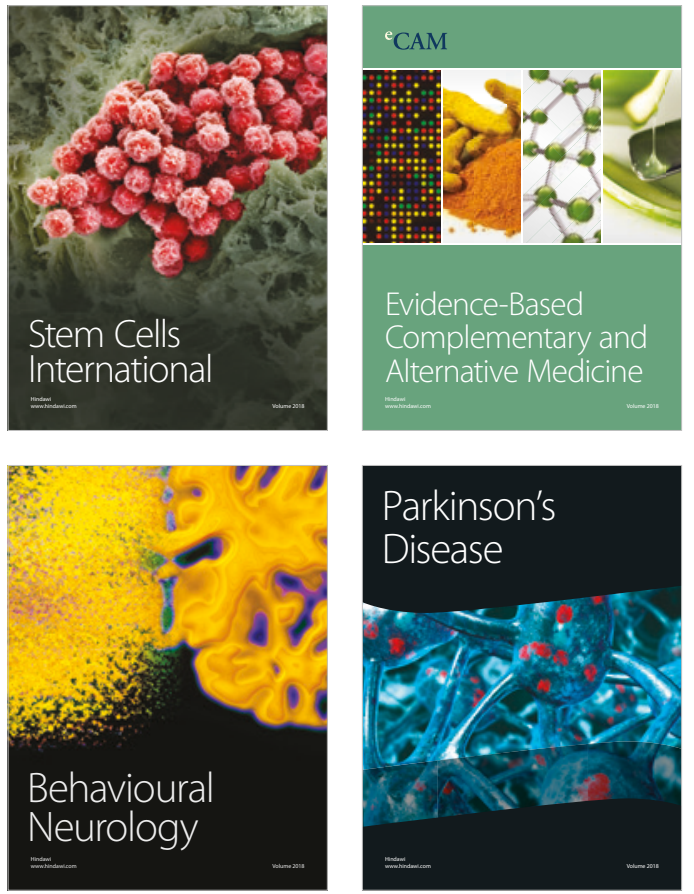

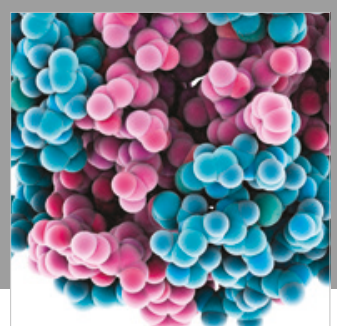

ournal of

Diabetes Research

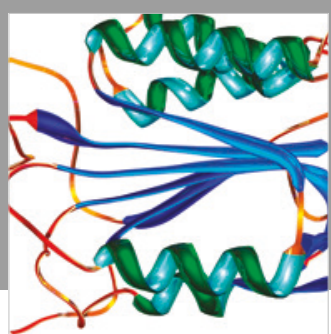

Disease Markers
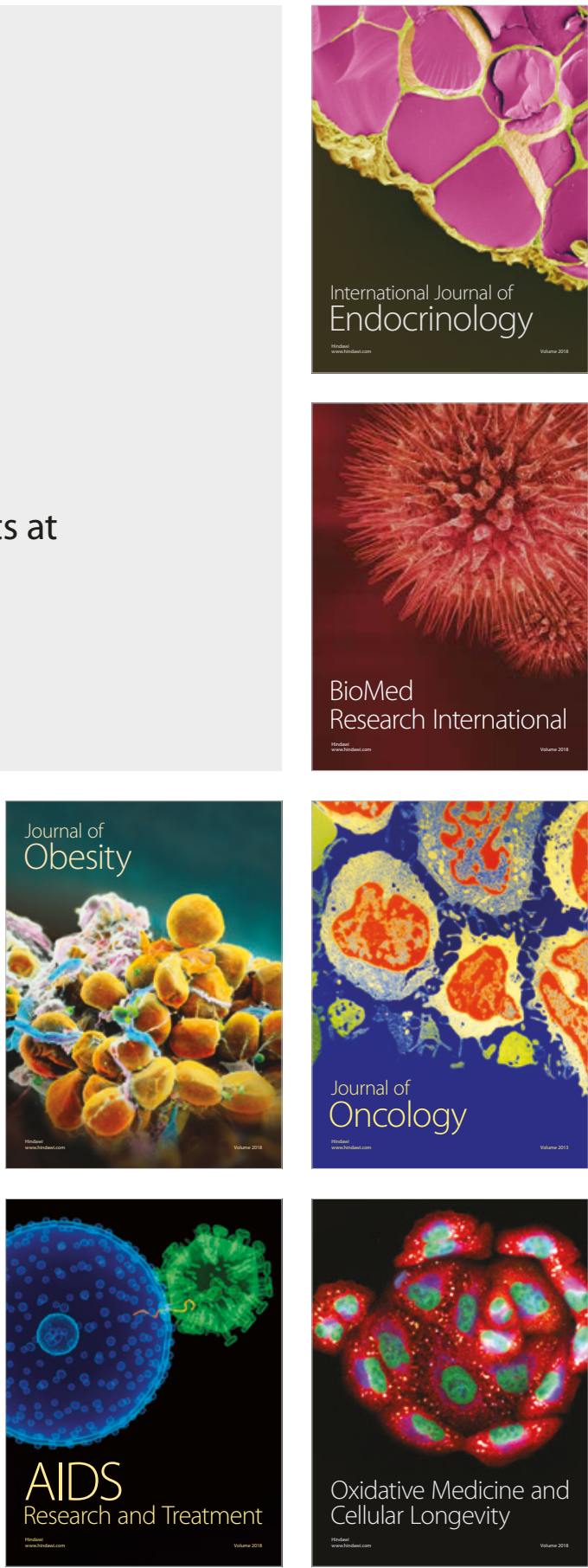